\title{
The Responsibility for Social Hope
}

\section{Marcus Morgan, University of Cambridge}

Since representations of social life are rarely separate from the worlds they aspire to capture, this article argues that as producers of such representations, sociologists are automatically responsible for considering the performative consequences of their work. In particular, it suggests that sociologists have an ongoing social responsibility to draw out emergent strands of hope from their empirical analyses. Through a comparison of Rorty, Levitas, and Unger's different theorisations of social hope, the article argues for a pragmatic form of hope that is rooted in an empirical conception of the past and present, but, alive to the transcendent possibilities of the emerging future, refuses to be restrained by this conception.

Keywords: hope; Unger; Rorty; Levitas; Ernst Bloch; performativity 
[T]o a very great extent, we dream our worlds into being

- Patricia J. Williams, 1997: 14.

One has to dream, but one has to dream in a pragmatic way

- Aldous Huxley, 1962.

Alongside a recent revival of interest in the significance of the principle of hope in the social sciences (Dinerstein, 2014; Holloway, 2014; Miyazaki, 2004; Swedberg, 2007; Thompson \& Žižek, 2013; Zournazi, 2003), this article makes the distinctly pragmatic argument that sociologists have an ongoing social responsibility to draw out emergent strands of hope from their analyses; to counter Gramsci's 'pessimism of the intellect' with a consistent and simultaneous 'optimism of the will'. This is because representations of social life are not separate from the worlds they aspire to capture, but immanent to those worlds, and therefore both influenced by, and capable of performatively affecting them. As producers of such representations, sociologists are therefore automatically and unavoidably responsible for considering the performative consequences that their projections are capable of engendering.

Through a comparison of Rorty, Levitas, and Unger's different theorisations of social hope, it argues for a form of hope that is rooted in an empirical conception of the past and present, but, alive to the transcendent possibilities of the emerging future, refuses to be restrained by this conception. On the one hand, it recognises the ideologically critical role played by fictional utopias produced within the imaginative arts. However, it argues that sociology's empirical basis places it in a stronger position than these idealist visions to produce socially-embedded, material, and emergent narratives of hope. On the other hand, in opposition to the attenuated version of the subject offered by structuralist and poststructuralist social theory, the understanding of hope defended here stresses the capacity for subjects to transcend the circumstances that constitute and bring them into being, and therefore against the notion of path-dependency, the possibility of the future presenting genuine, subjectively-determined novelty.

\section{A comparison of three theorisations of social hope}

We need history, certainly, but we need it for reasons different from those for which the idler in the garden of knowledge needs it ... We need it, that is to say, for the sake of life and action, not to turn comfortably away from life and action

- Fredrich Nietzsche

Men [sic] make their own history, but they do not make it just as they please; they do not make it under circumstances chosen by themselves, but under circumstances directly encountered, given and transmitted from the past. The tradition of all dead generations weighs like a nightmare on the brains of the living 
- $\quad$ Karl Marx, 1978: 439; 595.

We are made wise not by the recollection of the past, but by the responsibility for our future

- $\quad$ George Bernard Shaw, [1921] 1987.

Rorty's pragmatism emphasises the importance of adopting an historical perspective in considering viable hopes for the future. In other words, he stresses that reflection upon the future must be seen through a lens that is ground and shaped by a consideration of how we have come to arrive at the present. He writes that pragmatists 'are entirely at home with the idea that political theory should view itself as suggestions for future action emerging out of recent historical experience, rather than attempting to legitimate the outcome of that experience by reference to something ahistorical' (1999: 272). He looks to historical narratives as a condition of hope, because, he claims, 'social and political philosophy has always been and always ought to be parasitic on such narratives' (ibid.: 231). ' Hope, for Rorty, is therefore not exclusively about the future, but also about looking to the past in order to show 'what we might reasonably hope could happen in the future' (ibid.: 232).

Rorty is critical of examinations of the past that stop short of considering their implications for imagining what form the future might take, but at the same time insists that insights into the future gleaned through historical analysis must not be interpreted deterministically, and this absence of determination can be seen in his refusal to prophesy. In this, as Thompson notes, his understanding of hope resembles Ernst Bloch's in that 'the world is not something found but "in becoming" and what it becomes is dependent on what we make of it' (2008). Rorty calls this approach to the emergent possibilities of the future a kind of 'deliberate fuzziness' (1999: 28), which he contrasts with metaphysics - the doomed attempt to get at something clear, non-human and eternal. His 'criterionless hope' therefore offers a pragmatic substitute for the role that Truth plays in metaphysical philosophy, suggesting that 'philosophers became preoccupied with images of the future only after they gave up the hope of gaining knowledge of the eternal' (1995: 199). In this, Rorty draws upon Dewey (1938), who understood the purpose of philosophical enquiry as not to discover the essential Truth of a matter (something which he saw as impossible to identify), but instead to meet the temporary demands of the problem that had given rise to the need for enquiry in the first place.

In distinction to Rorty's relative emphasis on the past, our second thinker, Ruth Levitas, instead emphasises the importance of bringing imagined futures into the present. Taking her inspiration for thinking about the future from Bloch's discussion of the 'spirit of utopia' ([1964] 2000), she examines how 'hope' might be thought of as a property which does not in fact properly belong to the future, but is best understood as instead belonging to the present. Though Bloch was more critical of process philosophy than the pragmatists were (e.g. Bloch, [1958] 1995: 201-2), Levitas shows how he refusedalongside process philosophers - to distinguish between the reality of the present and the unreality of the future, instead pointing out how 'the world is always in process, essentially unfinished, so that anticipated futures are themselves part of the real, and the real always necessarily includes imagined 
and possible (as well as impossible) futures' (Levitas, 2004: 271). ${ }^{3}$

Levitas presents her utopian method as 'not just about the projection of a desired object to meet our needs, but a projected subject, ourselves, in some sense redeemed' (2005: 12). In the first instance at least, she therefore understands the value of utopian thinking as lying in its capacity to affect a change in subjects' imaginations by appealing to their ability to picture what it might be like to live in a radically different manner. However, unlike other contemporary sociological utopians (e.g. Wright, 2010), Levitas refuses to identify utopia with any particular time or place, and though this decision may appear to place her work outside the utopian tradition altogether, it in fact demonstrates a greater fidelity to the word's original Greek meaning: ou (no/not) topos (place) - 'no place' (OED). In distinction to the orthodox Marxist understanding of an eventual reconciliation of the societal dialectic, the utopian hope that Levitas discusses is never-ending; incapable of finding satisfaction in some future telos. This position is shared by the post-Marxist political theorists Laclau and Mouffe who draw upon Derrida's notions of 'undecidability' and 'democracy to come' to argue that democratic perfection must be seen as an ultimately impossible, yet simultaneously crucial, project:

it is vital to abandon any reference to the possibility of a consensus that, because it would be grounded on justice or on rationality, could not be destabilised. To believe in the possibility of such a consensus ... is to transform the pluralist democratic ideal into a "self-refuting ideal", since the very moment of its realisation would coincide with its destruction (Mouffe, 1996: 11; also Laclau and Mouffe, 2002: 123-8).

One consequence of Levitas's particular understanding of future possibilities as real and acutely necessary components of the present, involves substituting the notion of utopia as a goal, for the notion of 'utopia as a method'. Drawing upon H. G. Wells's suggestion that "the creation of utopias-and their exhaustive criticism - is the proper and distinctive method for sociology" she argues that "by thinking about utopia as a method we can address more effectively major problems that confront us' (2005: 8; 9). This project, which Levitas has more recently elaborated into a book-length exploration (Levitas, 2013), demands some degree of specificity in outlining visions of the good society, and she suggests that although it was chased out of the discipline during its development in the twentieth century, there are some promising signs of its recent reemergence (2013: 127-50).

One thinker who Levitas takes as representative of this recent revival, and the final thinker to be considered here, is Roberto Unger, whose conception of hope's relationship to different temporalities is congruent with aspects of both Rorty and Levitas. Like Levitas, he sees potential futures as integral aspects of the present, but uses this insight to radicalise the historicising aspects of the pragmatic tradition's attention to the past that Rorty stresses. Therefore, whilst paying respect to the contingency of the present upon the past, and the future upon the present, he stresses the ever-attendant possibility of the future transcending these conditions.

Unger (1987a) counsels us to examine the past closely both in order to learn likely future outcomes of a present left uninterrupted, and also in order to revive those subversive memories from the past that offer implicit critiques of the present. However, Unger's attention to the formative contexts 
of the past —what pragmatists call 'contingency' —at the same time objects to any understanding of this past that extrapolates from it a 'false necessity' into the emerging future. Such understandings are found across the political spectrum from deterministic faiths in immanent 'historical necessity', through to Hegelian 'end of history' theses that understand Western liberal democratic capitalism as the historical juncture beyond which nothing else lies. For Unger, all such positions cripple rather than inspire agents' capacities to act in the world by robbing humans of what most defines them: their 'negative capability' or capacity for transcendence from the past (Unger, 1987a: 277-312).

In arguing that 'the roots of a human being lie in the future rather than in the past' (2007: 238), Unger's version of hope, like Bloch's ([1958] 1995: 45), sees futurity not as a matter of choice but as a phenomenological component of the human condition. Nevertheless - pushing beyond the traces of Bergson that remain in Rorty and James - he believes this feature can become extended by human will so as to become a conscious endeavour: 'futurity', he writes, 'should cease to be a predicament and should become a programme: we should radicalise it to empower ourselves' (ibid.: 41). 'Empowerment' here means something more far-reaching than the management of inevitabilities because Unger argues that by self-consciously acting and thinking towards a future becoming, humans are to some degree able to escape, or transcend path-dependent historicity and create situations of genuine novelty, "things that are really new, in the sense that they do not just make real a possibility that had been backstage to the actual world, awaiting the events that would serve as its cue to step onto the stage of actuality' (ibid.: $34)$.

This radicalised conception of the transcendent promises built into the fabric of the present was expressed by Fanon too, who claimed that we should always understand 'the present in terms of something to be exceeded' (Fanon, [1952] 2008: 6). From this perspective, the past itself is seen as never entirely complete, not just in the trivial sense that time is continually passing and 'waits for no one', but in the more hopeful sense that the constraining sway of the past remains open to the transcendent possibilities of the present. Unger's vision for hope therefore shares something with Said's plea that we treat 'the past itself as still unresolved, still being made, still open to the presence and the challenges of the emergent, the insurgent, the unrequited, and the unexplored' (2004: 26). Combining elements found in both Rorty's and Levitas's models, he argues that although the past weighs down heavily upon the present, by wilfully directing ourselves towards images of the future there always remains the possibility of shaking-off the burden of history. Rather than closing the future down before it has happened (by seeing it as necessarily conforming to the past) Unger's vision therefore leaves the coming horizon open to the possibility of being recaptured by human hope, suggesting one way in which the minimal liberal and democratic implications of pragmatism (Morgan, 2013), might begin to be refashioned in a more radicalised form.

These variances in theorising the relationship between temporalities also imply different political possibilities that can be located along a spectrum stretching between the poles of realism and idealism. 'Realism' here can be thought of as emphasising the immanence of the emerging future, whilst 'idealism' might be seen as an effort to remain faithful to the future's transcendent capacity. 
Rorty is the theorist of hope whose political prescriptions lie closest to the 'real' and furthest from the 'ideal' because he argues that the basic form of liberal democracy operating in countries such as the United States is 'a way of bringing people into some degree of comity, and of increasing human happiness which looks more promising than any other way which has been proposed so far' (1999: 273). His commitment to pragmatism allows him no non-human justification for this belief, but he defends it through claiming that after experiencing life under such a system, nobody would choose to live under any other (Rorty, 1991: 29). This claim however, depends upon demoting the significance of political dissent that exists within liberal democracies. The presence of so-called 'homegrown terror', for instance, is only the most dramatic and destructive demonstration of the fact that not everyone living within the Western world automatically reaches the same conclusions as Rorty. Indeed, it might be argued that the greatest challenge for the world's most dominant liberal democracies in recent years has been how to deal with those insiders who apparently fail to spontaneously adopt their own 'core values', whilst simultaneously retaining their own liberal-democratic integrity, a matter upon which they can hardly claim to have achieved a great deal of success.

Although critical of many of America's specific policies, Rorty nevertheless sees the general model it presents to the rest of the world as 'a good example of the best kind of society so far invented' (1999: 4). Sadly, such statements occlude understanding the manner in which the ‘American Dream' of freedom and upward social mobility has so often been employed as a classical political manipulation of the social hope that Rorty sketches on a theoretical plane. His tenacious defence of his own country's basic political values and institutions also appears, as Turner (2004) recognises, to reproduce precisely that which pragmatism (including Rorty himself, elsewhere) is so careful to avoid: an appeal to some kind of foundation as a surrogate version of Reality, Truth, or God. In Rorty's politics, the North American version of liberal democracy appears as the one contingent and historical construction that is continually justified and defended as if it were instead some timeless Truth of political organisation. On this point, Soper notes that 'for all the strictures against onto-theology and metaphysical closure it is not clear that Rorty is as much out of the wood on this as he likes to think himself' (2001: 122). Similarly, his professed faith in the tinkering of relatively recent liberal democratic institutions as constituting the ultimate horizon for our political hopes has been described by Unger and West as a 'doctrine of the one true way', which in practice involves 'inconclusive bargaining among organised interests about minor fix-its' (Unger and West, 1998: 2; 5). The upshot of this is a relatively conservative politics within which the furthest reach of social hope is the promise of gradual piecemeal reform occurring through an already more or less perfected institutional framework, a position we find mirrored in Europe in Giddens's (1990) call for 'realistic utopias'. For this reason, although Rorty's theoretical model of hope is useful in its grounding hope within analysis of past and present conditions, it fails to translate itself into an adequately affirmative and critical political stance. It therefore acts to restrain rather than radicalise the more progressive aspects of pragmatism's legacy, amounting politically to something akin to what Bloch once described as a 'dubious polishing of what exists' ([1959] 1995: 149). 
Levitas (2008) also critiques Rorty's co-option of utopian terminology in support of his 'realist' political programme, which she describes as little more than 'managerialism'. Levitas rejects outright the notion 'that "good" utopias must be realistic and practical' (Levitas, 2004: 269) and offers a quite different approach to politics that takes seriously the ' 68 slogan 'be realistic: demand the impossible'. She stresses that what is realistic and unrealistic is a political question, open to debate, and therefore that the "the call for "realistic" or "sensible" utopias suppresses the politics of categorisation behind the veneer of empiricism' (ibid.: 271). The politics that she appears to be behind starts from a debate over what a future 'ideal' state of affairs might look like, proceeding backwards towards the actual present in order to determine how such an 'ideal' might then be created. This is the inverse of what she argues that theorists such as Rorty do: begin with the present state of affairs and ask what can 'realistically' be done with them. Here, Levitas echoes Marcuse's warnings concerning the danger of an obsession with the empirical present as forming the boundaries of one's socio-political imagination because, as he put it, a "radical acceptance of the empirical violates the empirical, for in it speaks the mutilated, "abstract" individual who experiences (and expresses) only that which is given to him [sic] (given in a literal sense)' (Marcuse, 1964 [2002]: 187). Halting our hopes for the future at the boundaries of our empirical surroundings denies the exercise of a crucial second dimension of our human potential: our capacity to imagine, negate, and act beyond 'what is'.

Although Levitas is no doubt right about how Rortyesque calls for 'realistic' change often function as alibis for no authentic change at all, she is however wrong insofar as she rejects pragmatism as entirely and inevitably based 'on the supposition that radical change is not possible' (2004: 271). Whilst her attack on political 'realism' is justified, it is important to also recognise that there is at least some truth to certain predictable critiques of the utopian tradition; most obviously, that quixotic pie-inthe-sky utopias themselves often fall victim to a certain faux-radicalism. This is not only because within the utopian tradition energy has too often been expended on feeding the imagination rather than fuelling action - dreaming rather than doing — but also because such theories have often been so far out-of-touch with the form of the present or from an inductive understanding of actual processes of social change that they have lacked any viable method of transcending it. Just as most psychotherapeutic methods teach the difficulties of successfully changing the self without a degree of self-knowledge (usually involving a reconstructive confrontation with those past events through which the self was formed), social change must likewise proceed on an empirical awareness of the material conditions it intends to reckon with. Hope for what is in fact impossible-what Lauren Berlant (2011) has called 'cruel optimism' - can in fact serve to obstruct, rather than initiate social change. In some ways Marx's vision of a classless egalitarian future was, like the best utopias, also a profound achievement of the imagination. However, it was famously, and of course intentionally, ill-defined, and at the same time emphatically grounded in a necessary material examination of history's dialectical process of unfolding. In the Manifesto, Marx and Engels therefore praised utopian modes of socialism in their ideological content - their 'critical element' lying in their commitment to attacking 'every principle of existing society' - nevertheless, they saw them as fundamentally flawed politically in their refusal to address 
actual material forces, and hence their consideration of themselves as 'far superior to all class antagonisms' (1978: 498). In their critique of the Young Hegelians, Marx and Engels stressed that in,

direct contrast to German philosophy which descends from heaven to earth, here we ascend from earth to heaven. That is to say, we do not set out from what men [sic] imagine, conceive, nor from men as narrated, thought of, or imagined, in order to arrive at men in the flesh. We set out from real, active men (1978: 154).

Though Levitas herself disrupts the stability of these categories, most utopian literature tends to navigate the opposite course: starting from the 'ideal' and working back towards the 'real'. Whilst this utopian approach may be useful in terms of puncturing ideology and priming the imagination, and at the same time accepting the dangers outlined above with refusing to move beyond the observed world, such visions appear less useful in terms of providing forms of hope that are socially embedded in the worlds to which they intend to speak. The kind of hope that an empirical discipline like sociology is able to produce cannot remain reflective and 'ideal' as it might do in art, literature, or philosophy, but must instead emerge from the conditions to which it refers, whilst at the same time refusing to be determined by the overbearing presence and apparent obstinacy of such conditions.

Accepting the intense power that Gramsci's 'common sense' holds over one's ability to imagine beyond what currently exists, it should also be noted that the content of our utopian dreams and desires is inevitably shaped by a multitude of distorting influences, not least opportunist political interests or, within consumer capitalism, the ubiquitous, inescapable, and aggressive marketing of commodities. The result of this, as Bloch explored, is that the diminished ambitions of some uninspired politician or the fantasies of consumer ownership are as likely to populate everyday utopian dreams as are images of radically transformed societies. It also points towards the fact that although utopias may present themselves as purely imagined, they are in reality revealing stockpiles of the collective artifactual desires of the very societies that dream them up, or as Adorno put it, the "new is the longing for the new, not the new itself' ([1970] 2004: 41). This stresses not only the desirability of fashioning an emphatically emergent hope, but also, in a more philosophical sense, the practical impossibility of not doing so.

By conceiving of utopia as method, Levitas protects herself from much of this tendency, often found in the artistic utopian tradition, to lose touch with the realities of the present. Her writing also fortifies itself against detachment by drawing its inspiration from Bloch, since Bloch ([1958] 1995) consistently searched for glimpses of utopian yearning precisely within the empirical phenomena and ephemera of everyday life; in such things as myths, fairy tales, jokes, or even advertising. ${ }^{4}$ Similarly to Gramsci, he believed that 'false consciousness' itself contained critical and emancipatory elements, and that from the 'utopian surplus' found within forms of false consciousness could be drawn out our unconscious yearnings for a better world than that surrounding us.

However, even if utopianism manages to avoid confusing itself with making an absolute break from the realities of the present, it also presents the obstacle that heavenly conceptions are sometimes nightmare realities, and though it is certainly true that such arguments have too often been employed as 
pretexts for knee-jerk conservatism (e.g. Scruton, 2010; see also Gray, 2007; Jacoby, 2005), the putting into practice of utopian dreams has shown an historical propensity to corruption, perversion, and unpleasant surprise, through failure to accurately predict how an imagined reality will in fact be experienced, through insufficient analysis of the power of prior societal interests, and through the unforeseeable consequences of rapid social upheaval. As well as capturing the imaginations of many of the twentieth century's finest fiction writers, history itself has perhaps offered the best examples of such a slide from conceived utopia into actual dystopia.

Levitas's own solution to this particular danger of utopianism is to expose utopian proposals to exhaustive public critique so that the active and open participation of a broad range of citizens (and not merely experts, leaders, sociologists, or vanguards) will ensure the safety and viability of these ideas. She writes that,

if sociology has a role in positing alternatives for the future, as a method of addressing the future it should ... always demand from the audience a judgement, or at least a judgement about a judgement, rather than simply the presentation or imposition of a judgement (2005: 12).

In some ways this in fact casts Levitas as herself a de facto pragmatist, and indeed, although in its structure it is opposed to notions of utopia, Levitas (2008) argues that Unger's version of pragmatism lies closer to utopianism than he himself perhaps recognises. Either way, it seems clear that in order to be directly useful to politics in their practical suggestions, rather than simply their 'ideological content', such 'utopias' must always be emergent from empirical analysis of the circumstances they wish to address. Once this is insisted upon however, as both Bloch and Levitas do, the fantastical connotations of the term 'utopia' begin to lose their appropriateness, and the more materially-embedded connotations of the term 'hope' begin to suggest themselves as more fitting. Whilst an empirical discipline like sociology would therefore benefit from reviving a utopian sensibility, what might be called a 'Spirit of Utopia' (Bloch, [1918] 2000), the actual imaginative creation of fictional utopias appears to be a task best left to literature and other creative arts. However, what sociology should be deeply concerned with is the task of injecting 'The Principle of Hope' (Bloch, [1958] 1995) back into grounded sociological work.

Turning finally to Unger's pragmatic conception of social hope, though his basic posture faces hopefully towards the future, he is careful to also maintain a restraining fix upon the past. For instance, in discussing the utopian projection of a society without conflict, he writes that in 'any society like the societies we know in history this ideal of communal life can gain a semblance of reality only in certain privileged corners of experience' (1987a: 560).

The basic theme of Unger's politics involves a programmatic radicalisation of pragmatism in order to stress the future's responsiveness to subjective moulding. Since this involves the ability of the subject to exceed its formative conditions, it is therefore premised upon a far stronger account of the subject than that provided by most antihumanistic social theory. Although, for example, on a Foucauldian reading, structure may be seen as enabling or generative of subjectivity, the position defended here points to a fuller account of the subject as capable of surpassing the structures that may 
in various other ways enable or limit its expression. Whilst therefore (as sociology habitually demonstrates) antihumanistic forces are seen as shaping us in diverse and powerful ways, they "never shape us completely. Even when they do not invite us to defy and to change them, we can defy and change them nevertheless. There always remains in us a residue or a surfeit of untamed and inexhaustible capability' (Unger, 2007: 52). This 'residue', Unger proposes, represents 'the perpetual misfit between us and our situation' (ibid.: 53).

Marcuse ([1964] 2002) famously applied the term 'one-dimensional' to societies that had surrendered this 'residue' and traded substantive freedoms for consolatory comforts, distractions, and securities, and in discussing the constant mismatch between ourselves and our environment Unger marries the assertively hopeful elements of the pragmatic tradition with ways of thinking that resemble the forms of Marxist humanism that writers such as Marcuse represent.

However, where Marcuse diagnosed the 'novel feature' of 'advanced industrial societies' (both capitalist and communist) as 'the flattening out of the antagonism between culture and social reality through the obliteration of the oppositional, alien and transcendent elements' ([1964] 2002: 60), Unger instead insists that everyday life is saturated with possibilities of transcendence.

Unger's assertion that everything that exists 'can become something else when placed under resistance' (2007: 17) clearly takes issue with what he describes as the 'democratic perfectionism' of mainstream neo-pragmatism. He describes this political deployment of pragmatism as a 'heresy' that 'confines the promises of democracy and economic progress to a dogmatic institutional formula $-\mathrm{a}$ particular institutional version of representative democracy, of the market economy, and of a free civil society' (2007: 51), something he elsewhere calls 'institutional fetishism' (1986b). This heresy is, he writes, 'now armed and identified with the power of the United States,' stating that it 'is in the interest of humanity to resist it and to deny to its sponsors the prerogatives of Constantine' (2007: 51). It is this 'democratic perfectionism' that it was earlier argued occupies the place of the 'Absolute' or the 'True' in Rorty's political writings, and Unger offers a fine example of how a pragmatic outlook need not resort to such uncritical moorings. Against Rorty's methodological individualism and his faith in the liberal values of freedom and self-reliance, Unger instead asserts the collective values of solidarity and social interdependence and claims that any conception of hope that cannot see beyond current institutional frameworks fails insofar as it 'nails our interests, ideals, and collective self-understandings to the cross of contingent, time-bound institutions' (ibid.: 23).

Under the sway of successive antihumanistic paradigms, dominant trends within social theory have excelled in recent years in offering critical genealogies of the present, but appear at the same time to have lost this capacity for radical programmatic imaginings of our collective social future. Whilst Unger's proposals are conceived pragmatically — as experimental and continually open to revisionthey nevertheless demonstrate a theoretical form of hope, bold and intrepid enough to allow for fundamental systemic revision.

Unger critiques the imaginative narrowness of our current economic and institutional repertory' and advances a theoretical model that directs us towards reclaiming the current systemic 
order to work in the interests of collective social needs. The lion's share of his three volume Politics (1987a; 1987b; 1987c) is devoted to just such proposals, aimed at radically restructuring and genuinely democratising the economic, legal, and social frameworks of democratic societies - something de Sousa Santos (2007) has more recently termed 'democratising democracy'. Unger's practical political concern is to institutionalise experimental social innovation and change so that it becomes more commonplace, less risky, and most importantly, less dependent upon calamity or crisis.

Unger's resolute insistence upon the possibility of future society departing radically from the limits of its inherited form opens up performative space for a social hope based upon realities, in Bloch's ([1959] 1995) terminology, 'not yet' present. Nevertheless, in his acknowledgment of the necessity of improvising and dealing with what is present in the world, Unger is no simple 'idealist' either; 'realism' is also strongly evident, as long as we reject, as he asks us to, the notion that 'realism means simply remaining close to what already exists' (ibid.: 33). Instead, he navigates a middle path between acknowledgement of a relatively intractable present and our imaginative dreams of what a better future might hold, writing that 'any social theory that would escape the illusion of false necessity without surrendering to the fantasies of unchastened utopianism must make sense of this clash between selffulfilling prophesies and recalcitrant facts' (2007: 34). This hopeful marriage of 'realism' and 'idealism' locates Unger firmly within the original spirit of the classical pragmatists, who, as Bernstein points out, 'emphasised how concrete inquiry is grounded in a specific existential and cultural context, a specific lifeworld, and at the same time endeavours to transcend the limitations of context' (1992: 834).

\section{The performative responsibility for social hope}

As was identified in the earlier discussion of hope's relationship to different temporalities, the value of sociological research that demonstrates the immense past and present power of antihumanistic mechanisms over the comparatively frail evidence of subjects overcoming such mechanisms lies in its ability to point towards more successful ways of resisting such seemingly insurmountable mechanisms in the future. In other words, such research is able to map appropriate targets for social hope, as well as discern pre-existent germs of hope within the social present that might be identified, drawn out, and productively developed. As Plummer notes, sociology ought to facilitate 'both positive thinking (looking for how things in the social world can be made better) whilst regularly engaging in critique', even though maintaining "this balance and not drowning in the empirically observable "misery of the world" is a perpetual challenge' (2010: 200). Examples of social theory alive to this 'doubleness' are not of course only found within the pragmatic tradition, but within any stream of social thought that takes seriously the responsibility of discerning hopeful 'becomings' within a sober-and occasionally demoralising - analysis of reality. This approach is arguably also the modus operandi of another group of radical thinkers, including Alain Badiou, Michael Hardt, Antonio Negri, and Paolo Virno, who, taking inspiration from Marx's distinction between 'real' and 'formal' subsumption, share a concern with detecting embryonic hope within the social realities towards which their critiques are directed, with the shared purpose of understanding 'when and how the possible becomes real' (Hardt and Negri, 
2000: 411).

Sociology working in the opposite direction, and presenting empiricism as a justification for social and political surrender can be seen to have relinquished the responsibility for uncovering latent social hope within the present. The reason why this task must be understood as a matter of ongoing responsibility (rather than simply an aspiration for the discipline) is because from a pragmatic perspective, sociology's apparently detached nature is put into question. Rather than being understood as merely a floating analysis, interpretation, or reading of the social world, sociology must instead be recognised as performative: capable of intervening in the social processes it takes interest in. Bourdieu was well aware of this performative quality of sociological work in commenting that,

even the most strictly constative scientific description is always open to the possibility of functioning in a prescriptive way, capable of contributing to its own verification by exercising a theory effect through which it helps to bring about that which it declares (1991: 134).

Likewise, insofar as Marx and Engels were attempting to conjure up a movement they were ostensibly merely observing in The Manifesto, they were themselves similarly aware of the performative role of social analysis. The tradition of 'labelling theory' in interactionist sociology has also taken an interest in how definitions of social reality themselves play a powerful role in constructing the reality they categorise (e.g. Becker, 1963), and more recently Ian Hacking (1999) has described the influence of classifications of people upon the people they classify as 'looping effects'. Hacking in fact journeys a step further than most in looking at how the changes in those thus classified, in turn recursively effect the classifications. Actor-network theorists and others have also shown awareness of how 'the stories of social theory are performative, not innocent' and therefore that social 'reality is not destiny', and 'what is real can be remade' (Law, 2007: 16; also Callon, 1998; MacKenzie, 2006) because, as Mol puts it, 'reality does not precede the mundane practices in which we interact with it, but is rather shaped within these practices' (1999: 75). Elsewhere, Law and Urry write that to

the extent that social science conceals its performativity from itself it is pretending to an innocence that it cannot have. And to the extent that it enacts methods that look for or assume certain structural stabilities, it enacts those stabilities while interfering with other realities' (Law and Urry, 2004: 10; also Law, 1998).

Such insights are entirely congruent with the pragmatic arguments for asserting social hope outlined above, and they pose a challenge in terms of deciding upon the sorts of realities sociology wishes to help enact. Mol (1999) calls this question one of 'ontological politics', a question concerning 'what is or could be made more real' (Law \& Urry, 2004: 5). In positing that hope is a matter upon which sociology stands to potentially affect that which it ostensibly merely studies, this paper is therefore in strong agreement with Law et al.'s arguments concerning the performativity of the social sciences and the agency of theory. However, it diverges from these arguments in their acceptance of the 'commonplace that the subject is decentred' (ibid.: 8) and therefore their failure to recognise that building their own analyses upon 'posthumanist' assumptions may itself serve to performatively deplete, rather than replenish, our resources of social hope. 
Unger, on the other hand, locates the subject as the source of bridging the divide between hope and change. As subjects themselves, sociologists, in this image, therefore becomes burdened with the unavoidable duty of asserting more fully the picture of ourselves as 'the context-bound yet contextresistant and context revising agents we really are' (1987b: 200). Himself alive to the performative nature of theory, Unger's hopeful assertion is that humans can,

redirect thought and reorganise society so that the vision of the agent able to use contingency against constraint becomes more real, and the picture of the toolmaker made into a tool of natural processes indifferent to his concerns becomes less real (2007: 35).

\section{The End of History or Back to the Future?}

these days, social scientists are concerned with what is, perhaps with what has been, but very rarely with what could be

- Michael Burawoy, 2011.

the taboo is broken; we do not live in the best possible world; we are allowed, obliged even, to think about alternatives

- Slavoj Žižek, 2011.

The argument of this paper has been that an important element of sociology's value lies not simply in its ability to offer an informed account of 'what is' or 'what has been', but moreover to offer hopeful visions of 'what might yet be'; to connect, as Unger puts it, 'insight into the actual' with 'imagination of the possible'. It has suggested that the pursuit of dry empiricism alone neglects the full potential of sociological knowledge, and has instead argued for a hopeful, yet 'anti-necessitarian' and non-prophetic sociology, attuned to the emergent, the possible, and the becoming. Avoiding both the romantic pitfalls of much utopian theory, as well as the inherent conservatism of the more moderate and 'realist' wing of neo-pragmatism, it has argued that such a conception can offer materialist visions of hope that nevertheless refuse to be deterministic. Furthermore, there is reason to believe that this capacity of sociology to sustain the possibility of authentic alternatives to the narrow range of social futures that politicians routinely lay out before us may be particularly relevant and valuable at the current conjuncture. Against a predominant politics of fear, sociology might play its own role in opening up space for a politics of hope.

Drawing upon Žižek’s $(2008 ; 2010)$ analysis of the powerful ideologies through which we live our lives, Fisher has argued that 'Fukuyama's thesis that history has climaxed with liberal capitalism may have been widely derided, but it is accepted, even assumed, at the level of the cultural unconscious' (2009: 7). This diagnosis in part demonstrates the hegemonic success achieved by the right in naturalising the social and economic consensus that has come to dominate the imagination and policy of almost all Western governments, and almost all international and global governance institutions, since at least the 1980s, a period in which Margaret Thatcher periodically reminded any possible 
doubters of her doctrine of TINA: that 'there really is no alternative' (Thatcher, 1980). With the fall of the Berlin Wall at the end of that decade, history itself appeared to have demonstrated the self-evident nature of the argument: free-market capitalism was the only game in town, and it was here to stay, indefinitely.

Counter-narratives to this model have of course been enduringly present, and not least those expressed within the World Social Forums and their various regional offshoots which have adopted as their motto precisely the opposite sentiment; that 'Another World Is Possible'. The economic crisis that hit in 2008 has also inflicted a blow to the ideological hegemony of the 'doctrine of the one true way' (Unger and West, 1998: 2) and cleared space even within establishment circles to begin seriously questioning the projection of the current liberal economic consensus into an indefinite future to the extent that in many quarters, such a projection itself now appears utopic (Žižek, 2010: 1-54). Leaving aside the reliance of this consensus upon the generation of stark inequality and various other social ills, one obvious practical reason that suspicion is mounting towards the 'end of history' thesis is, as Graeber reminds us, that an 'engine of infinite expansion and accumulation cannot, by definition, continue forever in a finite world' (2007). However, Graeber adds that whatever it is that replaces our current social system, 'there is no guarantee that this something will be better. It might be considerably worse', and therefore, he asks, 'Might we not do well at least to consider what something better might be like?' (ibid.). This paper has suggested that sociology is not just well placed in contributing to this task of imagining and debating 'what something better might be like', but that it is obligatorily implicated in it: that its performative nature means that whether or not it is conscious of itself as being so, it is unavoidably part of the ideological struggle over defining the possibilities of what the future social order might hold.

\footnotetext{
${ }^{1}$ Such an image of the task of social science is similar to Keynes's characterisation of the 'master economist', as one who studies 'the present in light of the past for the purpose of the future' (Keynes, 1924: 322).

2 James read Bergson with great enthusiasm, lauding his work as containing 'exquisite genius' (Richardson, 2007: 424-8).

${ }^{3}$ A similar idea as is expressed through Deleuze's (2002) notion of the 'virtual'.

${ }^{4}$ Marcuse and Adorno also recognised how certain forms of music, art, and other creative cultural expressions broke with what Freud had called the 'reality principle' and in so doing offered glimpses of what an unalienated life might look and feel like.
} 


\section{References}

Adorno, T., ([1970] 2004), Aesthetic Theory, London: Continuum Impacts.

Becker, H., (1963), Outsiders: Studies in the Sociology of Deviance, New York: The Free Press.

Berlant, L., (2010), Cruel Optimism, London: Duke University Press.

Bernstein, R. J., (1992), 'The Resurgence of Pragmatism', Social Research, Vol. 59 (4), pp. 813-840.

Bloch, E., ([1918] 2000), The Spirit of Utopia, Stanford CA: Stanford University Press.

Bloch, E., ([1959] 1995), The Principle of Hope: Volume 1, Massachusetts: MIT Press.

Bourdieu, P., (1991), Language \& Symbolic Power, Cambridge: Polity Press.

Burawoy, M., (2011), 'Response to Russell Jacoby's review of Erik Olin Wright's Real Utopias', Dissent Magazine, February, 2011: http://www.dissentmagazine.org/online.php?id=445.

Callon, M., (1998), 'Introduction: the Embeddedness of Economic Markets in Economics', in Callon, M., (ed.), The Laws of the Markets, Oxford: Blackwell.

de Sousa Santos, B., (2007), (ed.), Democratizing Democracy: Beyond the Liberal Democratic Canon, London: Verso.

Deleuze, G., (2002), 'The Actual and The Virtual' in Dialogues, New York: Columbia University Press.

Dewey, J., (1938), Logic: The Theory of Enquiry, New York: Henry Holt \& Co.

Dinerstein, A. C., (2014), The Politics of Autonomy in Latin America: The Art of Organising Hope, Basingstoke: Palgrave Macmillan.

Fanon, F., ([1952] 2008), Black Skin, White Masks, London: Pluto Press.

Giddens, A., (1990), The Consequences of Modernity, Stanford, CA: Stanford University Press.

Graeber, D., (2007), 'Letter in response to Žižek, "Residence is Surrender"', The London Review of Books, Vol. 29, No. 22, $15^{\text {th }}$ Nov, 2007.

Gray, J., (2007), Black Mass: Apocalyptic Religion and the Death of Utopia, New York: Farrar, Straus and Giroux.

Hacking, I., (1999), The Social Construction of What?, Cambridge MA, Harvard University Press.

Hardt, M. \& Negri, A., (2000), Empire, Cambridge, MA: Harvard University Press.

Holloway, J., (2014), 'Hope and Crisis', Sociology, vol 48 (5), pp. 1070-1072.

Huxley, A., (1962), 'Sum and Substance with Aldous Huxley', Huxley interviewed by Harvey Herman at the University of Southern California, KNXT Public Affairs.

Jacoby, R., (2005), Picture Imperfect: Utopian Thought for an Anti-Utopian Age, New York: Colombia University Press.

Keynes J. M., (1924), 'Alfred Marshall, 1842-1924', The Economic Journal, Vol. 34, No. 135, pp. 311-372.

Laclau, E., \& Mouffe, C., (2002), 'Hope, Passion, Politics' in Zournazi, M., Hope: New Philosophies for Change, London: Lawrence and Wishart.

Law, J. \& Urry, J., (2004), 'Enacting the Social', Economy and Society, 33 (3): 390-410. 
Law, J., (2007), ‘Actor Network Theory and Material Semiotics,' version of 25th April 2007, http://www.heterogeneities.net/publications/Law2007ANTandMaterialSemiotics.pdf, last accessed, 16th Dec 2011.

Levitas, R., (2004), 'Hope and Education by David Halpin, Review Article', Journal of Philosophy of Education, Vol. 38, No. 2, pp. 269-273.

Levitas, R., (2005), 'The Imaginary Reconstitution of Society', or, 'why sociologists and others should take utopia more seriously', Inaugural Lecture, University of Bristol, $24^{\text {th }}$ October, 2005 .

Levitas, R., (2008), 'Pragmatism, Utopia, and Anti-Utopia, Critical Horizons, Vol. 9, No. 1, pp. 4259.

Levitas, R., (2013), Utopia as Method: The Imaginary Reconstruction of Society, London: Palgrave Macmillan.

Mackenzie, D., (2006), 'Is Economics Performative? Option theory and the Construction of Derivates Markets', Journal of the History of Economic Thought, Vol. 28, No. 1, pp. 29-55.

Marcuse, H., ([1964] 2002), One-Dimensional Man: Studies in the Ideology of Advanced Industrial Society, London: Routledge.

Marx, K., (1978), The Marx-Engels Reader, Tucker, R., (ed.), New York: Norton.

Miyazaki, H., (2004), The Method of Hope: Anthropology, Philosophy, and Fijian Knowledge, Stanford University Press.

Mol, A., (1999), 'Ontological Politics: A Word and Some Questions', in Law, J., and Hassard, J., Actor-Network Theory and After, London: Blackwell.

Morgan, M., (2013) 'Revisiting Orwell and Rorty on Freedom and Truth', Philosophy and Social Criticism.

Mouffe, C., (1996), 'Deconstruction, Pragmatism, and the Politics of Democracy', in Critchley, S., and Mouffe, C. Eds., Deconstruction and Pragmatism, London: Routledge.

Richardson, D.R., (2007), William James: In the Maelstrom of American Modernism, Boston: Marnier Books.

Rorty, R., (1988), 'Unger, Castoriadis, and the Romance of a National Future, Northwestern University Law Review, 2 Nw. U.L. Rev. 335.

Rorty, R., (1991), Objectivism, Relativism and Truth, Cambridge: Cambridge University Press.

Rorty, R., (1995), 'Philosophy and the Future.' in Saatkamp, H., ed., Rorty And Pragmatism: The Philosopher Responds To His Critics, Nashville, TN: Vanderbilt University Press.

Rorty, R., (1999), Philosophy and Social Hope, London: Penguin Books.

Said, E., (2004), Humanism and Democratic Criticism, New York: Palgrave.

Scruton, R., (2010), The Uses of Pessimism and The Dangers of False Hope, Oxford: Oxford University Press.

Shaw, G. B., ([1921] 1987), Back to Methuselah, London: Penguin Books.

Soper, K., (2001), 'Richard Rorty: Humanist and/or Anti-humanist?' in Festenstein, M. and 
Thompson, S., (eds.), Richard Rorty: Critical Dialogues, Oxford: Polity.

Swedberg, R., (2007), 'The Sociological Study of Hope and the Economy: Introductory Remarks', Hope Studies Conference, University of Tokyo.

Thatcher, M., (1980) 'Press Conference for American correspondents in London', 25 June, 1980, http://www.margaretthatcher.org/Speeches/displaydocument.asp?docid=104389\&doctype=1, last accessed, 15th June, 2015.

Thompson, P., (2008), 'Heidegger, Rorty, Bloch, Marx, and Pragmatism', blog entry, http://ernstbloch.wordpress.com/, March $28^{\text {th }} 2008$.

Thompson, P., \& Žižek, S., (Eds.), (2013), The Privatisation of Hope: Ernst Bloch and the Future of Utopia, Durham, NC: Duke University Press.

Turner, B. S., (2004), 'Democracy in One Country?: Reflections on Patriotism, Politics and Pragmatism', European Journal of Social Theory, Vol. 7 (3), pp. 275-289.

Unger, R. M., (1987a), False Necessity: Anti-Necessitarian Social Theory in the Service of Radical Democracy: Volume 1 of Politics, A Work in Constructive Social Theory, Cambridge: Cambridge University Press.

Unger, R. M., (1987b), Social theory: Its Situation and Its Task: A Critical Introduction to Politics, A Work in Constructive Social Theory, Cambridge: Cambridge University Press.

Unger, R. M., (1987c), Plasticity into Power: Comparative Historical Studies in the Institutional Conditions of Economic and Military Success, Cambridge: Cambridge University Press.

Unger, R. M., (2007), The Self Awakened: Pragmatism Unbound, Cambridge, MA: Harvard University Press.

Unger, R. M., \& West, C., (1998), The Future of American Progressivism: An Initiative for Political and Economic Reform, Boston: Beacon Press.

Williams, P. J., (1997), Seeing A Colour-blind Future: The Paradox of Race, New York: Farrar, Straus \& Giroux.

Wright, E. O., (2010), Envisioning Real Utopias, London: Verso.

Žižek, S., (2008), In Defence of Lost Causes, London: Verso.

Žižek, S., (2010), Living in The End Times, London: Verso.

Žižek, S., (2011), 'Occupy First, Demands Come Later', The Guardian, $26^{\text {th }}$ October, 2011.

Zournazi, M., (2003), (ed.) Hope: New Philosophies for Change, London: Lawrence and Wishart. 